Bicarbonate threshold extracellular water kidney oculo-cerebro-renal syndrome titratable acidity tubular acidosis

\title{
The Influence of Extracellular Fluid Volume on the Renal Bicarbonate Threshold. A Study of Two Children with Lowe's Syndrome
}

\author{
Oskar Oetliker $^{[23]}$ and Ettore Rossi \\ Department of Pediatrics, University of Berne, Switzerland
}

\section{Extract}

This study on the renal acid-base balance in two slightly acidotic patients with Lowe's syndrome was undertaken to demonstrate the influence of extracellular fluid volume on the renal bicarbonate threshold. The clinical observation of chronic dehydration in both patients lead to the hypothesis that a low plasma volume might account for a relative compensation of metabolic acidosis in these patients and, conversely, that volume expansion might unmask a more severe acidosis.

The ability to excrete an acid urine was established by measuring the response to acute $\mathrm{NH}_{4} \mathrm{Cl}$ loading. Optimal response was seen three to four hours after $\mathrm{NH}_{4} \mathrm{Cl}$ was given. Both patients were able to excrete acid urine with a $\mathrm{pH}$ of 5.5 at blood total $\mathrm{CO}_{2}$ content below $18.5 \mathrm{mmoles} / \mathrm{l}$. The excretion rates for titratable acidity (TA) and for ammonium rose after $\mathrm{NH}_{4} \mathrm{Cl}$ administration to values within normal range (table I). The excretion rate of TA in one patient attained normal limits after correction for the low GFR, which on repeated examinations was 25-30\% of normal.

The renal bicarbonate threshold was determined by infusions of increasing amounts of $\mathrm{NaHCO}_{3}$. The infusion rates were kept constant at $1.4 \mathrm{ml} / \mathrm{min} / \mathrm{m}^{2}$ during the first study undertaken in each patient, and $5.6 \mathrm{ml} / \mathrm{min} / \mathrm{m}^{2}$ during the second. With low infusion rates, plasma volume, determined by the radioisotope dilution technique, was $57.8 \mathrm{ml} / \mathrm{kg}$ in Patient C.St. and $54.5 \mathrm{ml} / \mathrm{kg}$ in Patient M.B.; during high infusion rates it was $63.6 \mathrm{ml} / \mathrm{kg}$ in Patient G. St. and $64.9 \mathrm{ml} / \mathrm{kg}$ in Patient M.B. Plasma volume was thus expanded 10 and $19 \%$, respectively, from one study to the next. During low rates of infusion, the renal bicarbonate threshold in both patients was $21 \mathrm{mmoles} / 1$ (tables II and III and fig.2); during high infusion rates it was 17.5 mmoles/l (tables IV and V and fig. 2). During low infusion rates, the bicarbonate thresholds were decreased, in comparison with the normal for age, 22-24 mmoles/1, and with the normal for weight, 21.5-22.5 mmoles/l. After expansion of extracellular fluid volume, the renal bicarbonate threshold decreased by 3.5 mmoles/l.

\section{Speculation}

The renal bicarbonate threshold can be decreased by volume expansion. In patients with Lowe's syndrome, chronic dehydration may compensate in part for the decreased renal bicarbonate threshold. 


\section{Introduction}

The renal contribution to acid-base balance can be quantitatively documented by means of two standardized tests [4]. With an acute loading test using ammonium chloride administered per os, quantitation of renal hydrogen ion excretion is possible [5], whereas by means of a bicarbonate titration test, the renal handling of bicarbonate can be described. Thus it is possible to differentiate between distal and proximal tubular acidosis.

LAMY et al. [8] reported that the oculo-cerebro-renal disorder known as Lowe's syndrome presents a defective renal bicarbonate reabsorption. In this study, a defective renal ammoniogenesis was also suspected.

The pathogenesis of the renal tubular defect in this syndrome is not known, but pathophysiologic considerations might contribute to a better understanding of the renal disorder. KunAu et al. [7] and Purkerson et al. [12] have shown in animal experiments that renal bicarbonate reabsorption is not of fixed magnitude, but is significantly influenced by the same stimuli that change sodium reabsorption independently of GFR and of the actual level of mineralocorticoids. The main stimulus to produce natriuresis in experimental work is the acute expansion of extracellular fluid volume. The mechanisms involved correspond to the so-called third factor.

Two patients with Lowe's syndrome, examined in the Pediatric Department of the University Hospital of Berne, exhibited a slight acidosis and a slight chronic dehydration. They were used as a clinical model in which the influence of extracellular fluid volume on the renal bicarbonate threshold could be examined in man.

\section{Case Histories}

M.B., a 25-month-old male, was the second child of unrelated, healthy parents. The first child was born ten weeks before term. The obstetrician reported the presence of a hydramnion. The male premature died of cerebral hemorrhage on the fourth day of life. Among other members of the family was one with chronic renal disease and one with diabetes; the mother was prediabetic. During the third month of the second pregnancy, vaginal bleeding and a febrile infection of short duration occurred. The mother gave birth to this child 5 weeks before term and again a hydramnion was observed. Birthweight was $2300 \mathrm{~g}$.

At birth, cataracts were present on both sides and a glaucoma was present on the left side. A distinct muscular hypotonia was noted immediately after birth. The reflexes were clearly diminished. During the first month of life, a pathologic hyperbilirubinemia persisted. Further findings noted during early infancy were proteinuria, cylindriuria, and pathologic leucocyturia. No hyperaminoaciduria or glycosuria could be documented. In the following month, statoponderal and psychomotoric retardation became increasingly apparent. The patient had recurrent episodes of fever of unknown origin.

At the age of 25 months, the child was again hospitalized; the following clinical findings were noted: weight, $7000 \mathrm{~g}$; length, $73.5 \mathrm{~cm}$; head circumference, $46.5 \mathrm{~cm}$. The patient was dystrophic with clearly diminished skin turgor and practically absent adipose tissue. Severe muscular hypotonia was also present and tendon reflexes were elicited only sporadically. Buphthalmus was present on the left. Digito-ocular phenomenon was frequently observed. Psychomotor development was of an age less than six months. Laboratory findings were as follows: hemoglobin, red and white blood counts, normal; $\mathrm{Na}, \mathrm{K}, \mathrm{Cl}, \mathrm{Ca}$ and $\mathrm{P}$ in serum, all within the normal range; $\mathrm{HCO}_{3}^{-}, 16.2-20.3$ mmoles/ $\mathrm{l}$; fasting glucose, $55-77 \mathrm{mg} / 100 \mathrm{ml}$; BUN, $17.9 \mathrm{mg} /$ $100 \mathrm{ml}$; cholesterol, $243 \mathrm{mg} / 100 \mathrm{ml}$; total protein, 7.27 $\mathrm{g} / 100 \mathrm{ml}$; SGOT, $50 \mathrm{U}$ (normal for age and method used 7-31 U) ; SGPT, $12.5 \mathrm{U}$ (normal range 0.8-11.6 $\mathrm{U}$ ); cholinesterase, $1235 \mathrm{U}$ (normal range 560-1490 $\mathrm{U})$; urine, ++ proteinuria; $\mathrm{pH}$ in randomly voided specimens, 6.1-7.8. Mild erythrocyturia and leucocyturia were present, but granular casts were rarely noted. There was slight generalized hyperaminoaciduria, and thin layer chromatography revealed no sugars in the urine. X-ray examination showed a bone age of 12 months.

C.St., a 26-month-old male, was the only child of unrelated, healthy parents. There was no relevant family history. The only complication during pregnancy was an episode of fever that occurred during the third month. Delivery at term was normal. Birth weight was $2810 \mathrm{~g}$ and length was $48 \mathrm{~cm}$. Immediately after birth, cataracts and a muscular hypotonia were noted. Within the first week of life, a glaucoma was also observed on both sides and the patient was transferred to an ophthalmological department for treatment. During infancy, a distinct stato-ponderal and psychomotoric retardation became apparent. A renal disorder with proteinuria, glycosuria, and hyperaminoaciduria was found and the diagnosis of cerebro-oculo-renal disease was established.

When at the age of 25 months this child was hospitalized, the following clinical findings were noted: a severely retarded boy weighing $7200 \mathrm{~g}$ with a length of $73 \mathrm{~cm}$. Head circumference was $45.5 \mathrm{~cm}$. The child was pale and dystrophic, with skin turgor slightly diminished. There was buphthalmus on both sides. Extreme muscular hypotonia was present; reflexes were 
absent. Psychomotor development was markedly retarded. Laboratory findings were as follows: hemoglobin, $10.9 \mathrm{~g} / 100 \mathrm{ml}$; leucocytes, 6800; differential blood count, normal; serum electrolytes, including $\mathrm{Na}$, $\mathrm{K}, \mathrm{Cl}, \mathrm{Ca}$, and $\mathrm{P}$, normal; blood $\mathrm{pH}, 7.363$; $\mathrm{pCO}_{2}$, 31.4; $\mathrm{HCO}_{3}^{-}, 19.0$; fasting glucose, $68 \mathrm{mg} / 100 \mathrm{ml}$; BUN, $25 \mathrm{mg} / 100 \mathrm{ml}$; cholesterol, $25 \mathrm{l} \mathrm{mg} / 100 \mathrm{ml}$; SGOT, $49 \mathrm{U}$ (normal range 6-22 U); SGPT, $18 \mathrm{U}$ (normal range 0.3-13.4 U); cholinesterase, $183 \mathrm{U}$ (normal range 560-1490 U); total protein, $7.8 \mathrm{~g} / 100$ $\mathrm{ml}$. Endogenous clearance of creatinine was $30.5 \mathrm{ml} /$ $\min / 1.73 \mathrm{~m}^{2}$, and urine was ++ proteinuria (mainly low molecular weight proteins). There was no glycosuria as estimated by thin layer chromatography, but there was slight generalized hyperaminoaciduria. The $\mathrm{pH}$ was about 6.3. There was no abnormal morphology of the sediment. X-ray examination showed a bone age of 16 months; calcification of the bones was clearly reduced.

\section{Methods}

In both patients the renal contribution to acid-base balance was evaluated according to the methods described by EDELMANN et al. [4].

\section{Acid Loading Test}

$\mathrm{NH}_{4} \mathrm{Cl}, 75 \mathrm{mEq} / \mathrm{m}^{2}$, was administered by stomach tube in a $10 \%$ aqueous solution during a period of 60 minutes. The procedure was well tolerated by both patients. Clearances of creatinine were determined before and after the tests. Before and after administration of $\mathrm{NH}_{4} \mathrm{CI}$, urine collections were obtained hourly for determination of titratable acid (TA) and of ammonium $\left(\mathrm{NH}_{4}\right)$ through an indwelling urethral catheter. Arterialized blood samples were obtained at free flow from the fingertip for determination of $\mathrm{pH}, \mathrm{pCO}_{2}$ and total $\mathrm{CO}_{2}$ content.

\section{Bicarbonate Titration}

Five to six hours before starting bicarbonate titration, $\mathrm{NH}_{4} \mathrm{Cl}$ was given orally as in the acid loading test in order to ensure a degree of acidosis below the renal bicarbonate threshold when the bicarbonate titration began. From the acid loading tests, it was known that the maximal response to $\mathrm{NH}_{4} \mathrm{Cl}$ was to be expected between the third and fourth hour after the administration of acid. Urine was collected through an indwelling urethral catheter, and venous blood samples were obtained from an indwelling needle that was flushed with a slightly heparinized isotonic saline solution after each sampling. Saline solution, $0.85 \% \mathrm{NaCl}$, was administered intravenously at a rate of $1.4 \mathrm{ml} / \mathrm{min} / \mathrm{m}^{2}$ during the first study, and at a rate of $5.6 \mathrm{ml} / \mathrm{min} / \mathrm{m}^{2}$ during the second. After a priming dose of inulin $10 \%$ of
$1 \mathrm{ml} / \mathrm{kg}$, the infusion contained inulin calculated to maintain a blood level of $50 \mathrm{mg} / 100 \mathrm{ml}$. Control clearance periods were taken, after which time bicarbonate was added to the infusion to increase the blood bicarbonate level about 2 mmoles $/ 1 / \mathrm{h}$. When the bicarbonate threshold was passed, as judged by an increase of urinary $\mathrm{pH}$ above 6.8 , bicarbonate administration was increased in one of four studies in order to obtain levels of blood bicarbonate more than 30 mmoles/l, a concentration known to eventually permit measurement of $T_{m}$ values for bicarbonate reabsorption.

\section{Laboratory Tests}

Blood and urine $\mathrm{pH}$ was measured at $38^{\circ}$ with a radiometer $22 \mathrm{pH}$ meter with Astrup microequipment. Measurements of $\mathrm{pCO}_{2}, \mathrm{HCO}_{3}^{-}$, and total $\mathrm{CO}_{2}$ content $\left(\mathrm{tCO}_{2}\right)$ were read from the Siggaard-Andersen nomogram. Urine was not collected under oil, since diffusibility between urine and oil is practically unrestricted. Urine was processed immediately. TA was measured at a room temperature of $25^{\circ} \mathrm{C}$ using a Metrohm $\mathrm{pH}$ meter Model E 396 B. The content of ammonium in urine was determined immediately after collection using the microdiffusion method of SELIGSON [18]. After diffusion, the amonium content was measured photometrically. The $\mathrm{tCO}_{2}$ of the urine was determined by the method of VAN SLYKE, using a Natelson microgasometer Model 600 [15]; $\mathrm{pCO}_{2}$ and bicarbonate were estimated as described by EDELMANN [5]. Concentrations of sodium and potassium were determined using an Eppendorf flame photometer. Inulin was determined according to the anthron method of DAvidson and SAckner [2]. Blood volume was estimated using the radioisotope dilution technique with $\mathrm{I}^{131}$ labeled human albumin.

\section{Results}

\section{Acid Loading Tests}

The response to oral $\mathrm{NH}_{4} \mathrm{Cl}$ loading was optimal during the fourth hour after administration. Control values were compared with the values obtained during the fourth hour (table I). In a third column of this table, the expected normal response established previously [5] is indicated. It can be seen that the urinary excretion rate of $\mathrm{TA}$ was within the expected limits of 26-70 $\mu \mathrm{Eq} / \mathrm{min} / 1.73 \mathrm{~m}^{2}$ in Patient M.B., but that 'normal' values were not reached in Patient C.St. Estimation of GFR in this patient repeatedly showed low values, $32 \mathrm{ml} / \mathrm{min} / 1.73 \mathrm{~m}^{2}$. If the excretion rate of TA was corrected for this low GFR, it was well within the expected range. Therefore, in table I, values for TA are also given corrected for actual GFR. The ex- 
cretion rate of $\mathrm{NH}_{4}^{+}$reached the expected range of $30-115 \mu \mathrm{Eq} / \mathrm{min} / 1.73 \mathrm{~m}^{2}$. The urinary $\mathrm{pH}$ changes after $\mathrm{NH}_{4} \mathrm{Cl}$ loading are seen in figure 1 . The relation between values for urinary $\mathrm{pH}$ and $\mathrm{tCO}_{2}$ shows the ability of the patients to excrete an acid urine ( $\mathrm{pH} 5.5)$ and demonstrates that the change from more alkaline to acid urine occurred at $\mathrm{tCO}_{2}$ values much lower than is normally observed, approximately $19-20 \mathrm{mmoles} / \mathrm{l}$.

\section{Bicarbonate Titrations}

Tables II and III present the results of the bicarbonate titrations in the two patients when the rate of infusion was $1.4 \mathrm{ml} / \mathrm{min} / \mathrm{m}^{2}$. If renal bicarbonate threshold is defined as the blood bicarbonate level corresponding to a urinary $\mathrm{HCO}_{3}^{-}$excretion rate of 0.02 mmoles/100 ml GFR, the threshold in Patient M.B. must lie between values of 20.6 and 22.5 mmoles/1 (table II). Using the same definition in Patient C. St.,
Table I. Response to $\mathrm{NH}_{4} \mathrm{Cl}$ loading ${ }^{1,2}$

\begin{tabular}{ccc}
\hline Control & Response & Expected \\
period & during & response \\
& 4 th hour & \\
& after \\
& challenge \\
\hline
\end{tabular}

C.St. M.B. C.St. M.B.

$\begin{array}{lrrrrc}\mathrm{pH} & 7.6 & 6.3 & 5.5 & 5.5 & 4.65-5.85 \\ \mathrm{TA} \mu \mathrm{Eq} / \mathrm{min} & 2.6 & 21.2 & 13.7 & 43.0 & 26-70 \\ \quad \mu \mathrm{Eq} / 100 \mathrm{ml} & 10.5 & 42.0 & 43.0 & 86.0 & \\ \quad \mathrm{GFR} & & & & & \\ \mathrm{NH}_{4} \mu \mathrm{Eq} / \mathrm{min} & 4.9 & 27.0 & 40.6 & 46.3 & 30-115\end{array}$

${ }^{1}$ Dose: $75 \mathrm{mEq} / \mathrm{m}^{2}$ given by mouth.

${ }^{2}$ All values given are corrected for surface area.

Table II. Study of Patient M.B. under conditions of low plasma volume

\begin{tabular}{|c|c|c|c|c|c|c|c|c|c|c|c|c|}
\hline \multirow{3}{*}{$\begin{array}{l}\text { Time } \\
\min \end{array}$} & \multicolumn{3}{|c|}{ Serum } & \multicolumn{5}{|c|}{ Urine } & \multicolumn{3}{|c|}{ Bicarbonate } & \multirow{2}{*}{$\begin{array}{l}\text { Plasma } \\
\text { volume }\end{array}$} \\
\hline & \multirow[t]{2}{*}{$\mathrm{pH}$} & \multicolumn{2}{|c|}{$\mathrm{PCO}_{2} \quad \mathrm{HCO}_{3}^{-}$} & $\mathrm{V}$ & $\mathrm{pH}$ & TA & $\mathrm{NH}_{4}^{+}$ & $\mathrm{C}_{\mathrm{In}_{\mathrm{n}}}$ & $\begin{array}{l}\text { Fil- } \\
\text { tered }\end{array}$ & $\begin{array}{l}\text { Ex- } \\
\text { creted }\end{array}$ & \multirow{2}{*}{$\begin{array}{c}\begin{array}{c}\text { Re- } \\
\text { ab- } \\
\text { sorbed }\end{array} \\
\text { l GFR }\end{array}$} & \\
\hline & & $\begin{array}{l}\mathrm{mm} \\
\mathrm{Hg}\end{array}$ & mmoles/I & $\begin{array}{c}\mathrm{ml} / \\
\mathrm{min} / \\
1.73 \mathrm{~m}^{2}\end{array}$ & & $\begin{array}{r}\mu \mathrm{Eq} \\
100 \mathrm{~m}\end{array}$ & $\begin{array}{l}/ \mathrm{min} / \\
\mathrm{l} \text { GFR }\end{array}$ & $\begin{array}{c}\mathrm{ml} / \\
\mathrm{min} / \\
1.73 \mathrm{~m}^{2}\end{array}$ & $\mathrm{mmo}$ & $\mathrm{es} / 100 \mathrm{n}$ & & $\mathrm{ml}$ \\
\hline $\begin{array}{r}-300 \\
\text { to }-240 \\
0 \\
10 \\
12\end{array}$ & $\begin{array}{l}\mathrm{NH}_{4} \mathrm{Cl} \\
7.22 \\
\text { priming } \\
\text { start inf }\end{array}$ & $\begin{array}{l}31.0 \\
\text { dose } 0 \\
\text { usion }\end{array}$ & $\begin{array}{c}12.2 \\
\text { f inulin }\end{array}$ & & & & & & & & & \\
\hline $\begin{array}{l}55-78 \\
79-99\end{array}$ & $\begin{array}{l}7.23 \\
7.24\end{array}$ & $\begin{array}{l}31.5 \\
30.5\end{array}$ & $\begin{array}{l}12.9 \\
12.8\end{array}$ & $\begin{array}{l}1.4 \\
1.37\end{array}$ & $\begin{array}{l}4.9 \\
4.95\end{array}$ & $\begin{array}{l}123 \\
129.3\end{array}$ & 83 & $\begin{array}{l}37.3 \\
34.7\end{array}$ & $\begin{array}{l}1.29 \\
1.28\end{array}$ & $\begin{array}{l}0 \\
0\end{array}$ & $\begin{array}{l}1.29 \\
1.28\end{array}$ & \\
\hline 101 & infusion & as abo & ve with as & ddition & & & & & & & & \\
\hline $\begin{array}{l}129-157 \\
158-190 \\
252-278 \\
279-309 \\
310-327\end{array}$ & $\begin{array}{l}7.26 \\
7.30 \\
7.33 \\
7.36 \\
7.38\end{array}$ & $\begin{array}{l}31.5 \\
30.5 \\
37.5 \\
36.5 \\
35.5\end{array}$ & $\begin{array}{l}14.6 \\
14.7 \\
19.4 \\
20.2 \\
20.6\end{array}$ & $\begin{array}{l}0.86 \\
1.09 \\
1.24 \\
2.0 \\
1.73\end{array}$ & $\begin{array}{l}5.1 \\
5.1 \\
5.8 \\
6.0 \\
6.15\end{array}$ & $\begin{array}{l}93 \\
94.6 \\
90.7 \\
75.0 \\
64.3\end{array}$ & $\begin{array}{c}86 \\
88.6 \\
152\end{array}$ & $\begin{array}{l}27.0 \\
33.2 \\
35.0 \\
55.4 \\
50.6\end{array}$ & $\begin{array}{l}1.46 \\
1.46 \\
1.94 \\
2.02 \\
2.06\end{array}$ & $\begin{array}{l}0 \\
0 \\
0 \\
0.002 \\
0.002\end{array}$ & $\begin{array}{l}1.46 \\
1.46 \\
1.94 \\
2.018 \\
2.058\end{array}$ & 381 \\
\hline 334 & infusion & as abo & ve with ac & ddition & & & & & & & & \\
\hline $\begin{array}{l}354-395 \\
396-415 \\
416-431\end{array}$ & $\begin{array}{l}7.41 \\
7.44 \\
7.44\end{array}$ & $\begin{array}{l}37.0 \\
36.0 \\
35.0\end{array}$ & $\begin{array}{l}22.5 \\
24.0 \\
23.5\end{array}$ & $\begin{array}{l}2.34 \\
3.12 \\
3.0\end{array}$ & $\begin{array}{l}6.89 \\
7.48 \\
7.59\end{array}$ & & & $\begin{array}{l}61.0 \\
59.8 \\
54.0\end{array}$ & $\begin{array}{l}2.25 \\
2.40 \\
2.35\end{array}$ & $\begin{array}{l}0.055 \\
0.206 \\
0.278\end{array}$ & $\begin{array}{l}2.195 \\
2.194 \\
2.072\end{array}$ & 383 \\
\hline $\begin{array}{l}{ }^{1} 1 \mathrm{~g} \text { give } \\
{ }^{2} 0.7 \mathrm{~g} . \\
{ }^{3} 2 \text { parts } \\
{ }^{4} \text { Contai } \\
{ }^{5} \text { Contai }\end{array}$ & $\begin{array}{l}\mathrm{NaCl} \text { a } \\
0 \mathrm{mmol} \\
\text { ditional }\end{array}$ & $\begin{array}{l}\text { ad } 1 \mathrm{p} \\
\mathrm{s} / \mathrm{HC} \\
260 \mathrm{~m}\end{array}$ & $\begin{array}{l}\operatorname{rt~} 5 \% \text { glu } \\
\mathrm{O}_{3}^{-} \\
\text {noles } / \mathrm{HC}\end{array}$ & $\mathrm{CO}_{3}^{-}$ & 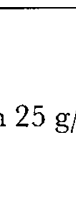 & inul & 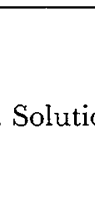 & , & stere & . & $1.4 \mathrm{r}$ & $\mathrm{n} / \mathrm{m}^{2}$ \\
\hline
\end{tabular}


a renal bicarbonate threshold of a little less than 21 mmoles/1 is observed (table III). Both patients appeared to exhibit approximately the same threshold. When the data obtained from the two studies are plotted together graphically (fig.2, solid circles), this finding is evident.

In tables IV and $\mathrm{V}$ are presented data of the repeated bicarbonate titrations using infusion rates of 5.6 $\mathrm{ml} / \mathrm{min} / \mathrm{m}^{2}$. The renal bicarbonate threshold could not be determined exactly in the study of Patient M.B., since despite acid loading four hours prior to the study, blood bicarbonate levels were not low enough at the beginning of the test (table IV). It can be seen, however, that the renal bicarbonate threshold was well exceeded at a blood $\mathrm{HCO}_{3}^{-}$of 19.6 mmoles/l. In $\mathrm{Pa}$ tient C.St., the renal bicarbonate threshold was 17.2 mmoles/l (table V). The data obtained during volume expansion in both patients appear graphically in figure 2 (ringed circles).

Plasma volumes are included in tables II to V. At renal bicarbonate threshold, plasma volume was expanded from $54.5 \mathrm{ml} / \mathrm{kg}$ to $64.9 \mathrm{ml} / \mathrm{kg}$ (19\%) in $\mathrm{Pa}$ tient M.B. and from $57.8 \mathrm{ml} / \mathrm{kg}$ to $63.6 \mathrm{ml} / \mathrm{kg}(10 \%)$ in Patient C. St.

Table III. Study of Patient C.St. under conditions of low plasma volume

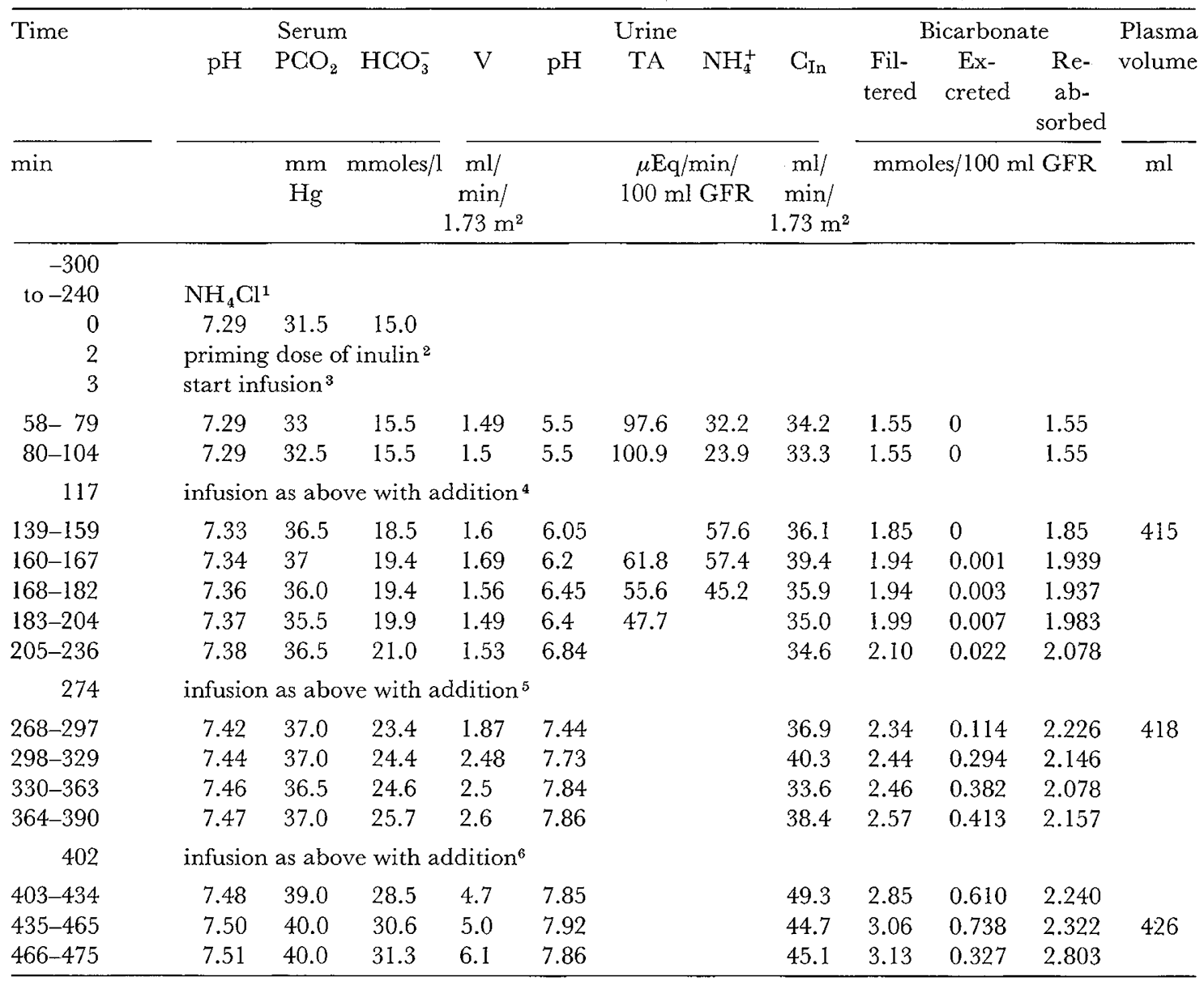

$1 \mathrm{~g}$ given by mouth in a $10 \%$ solution in water.

$20.8 \mathrm{~g}$.

32 parts $0.85 \% \mathrm{NaCl}$ and 1 part $5 \%$ glucose with $15 \mathrm{~g} / 1$ inulin. Solution administered at rate of $1.35 \mathrm{ml} / \mathrm{min}^{2} / \mathrm{m}^{2}$.

${ }^{4}$ Containing 300 mmoles $/ 1 \mathrm{HCO}_{3}^{-}$.

5 Containing additional 150 mmoles $/ 1 \mathrm{HCO}_{3}^{-}$.

${ }^{6}$ Containing additional 150 mmoles $/ 1 \mathrm{HCO}_{3}^{-}$. 


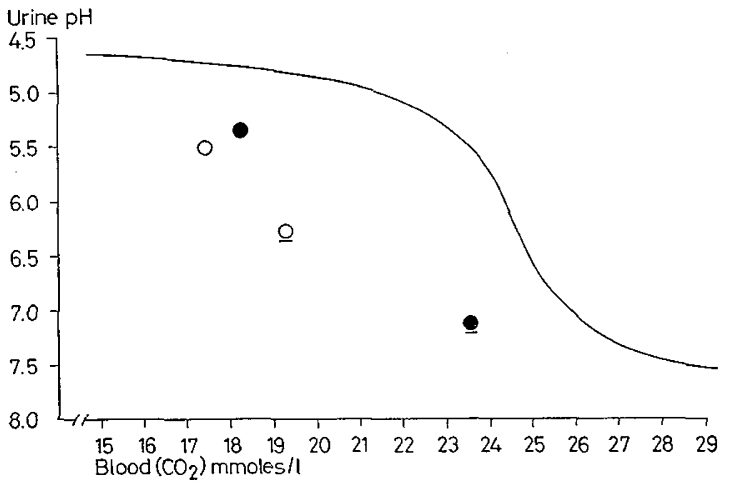

Fig. 1. Urinary $\mathrm{pH}$ as a function of total $\mathrm{CO}_{2}$ content of blood observed during ammonium chloride tests, (O) in Patient M. B. and (O) in Patient G. St. The S-shaped curve shows the normal [5] author check ref. No. relation. The underlined circles represent the data before, and the corresponding circles the data 4 hours after, ammonium chloride loading.

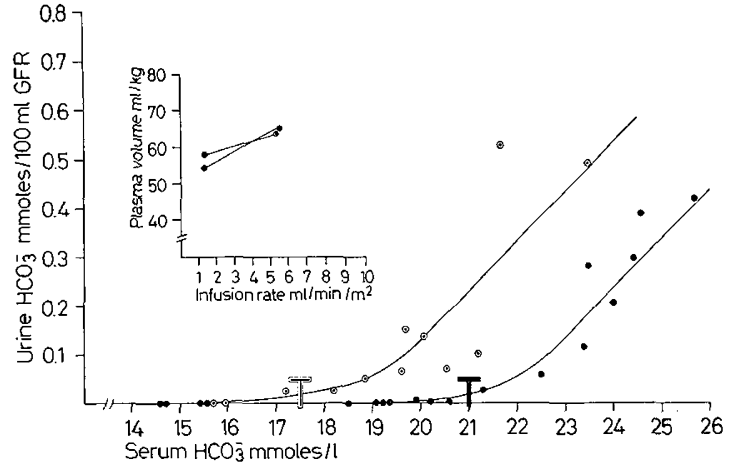

Fig.2. Urinary excretion rates of $\mathrm{HCO}_{3}^{-}$as a function of serum $\mathrm{HCO}_{3}^{-}$. The closed circles represent the data obtained from the two patients during infusion rates of $1.4 \mathrm{ml} / \mathrm{min} / \mathrm{m}^{2}$; the ringed circles show the data obtained during infusion rates of $5.6 \mathrm{ml} / \mathrm{min} / \mathrm{m}^{2}$. Changes in plasma volume with the increased infusion rates are seen in the inserted graph. The bicarbonate titration curves are drawn by inspection. T marks the bicarbonate thresholds.

Table IV. Study of Patient M. B. under conditions of high plasma volume

\begin{tabular}{|c|c|c|c|c|c|c|c|c|c|c|c|c|}
\hline \multirow[t]{2}{*}{ Time } & \multicolumn{3}{|c|}{ Serum } & \multicolumn{5}{|c|}{ Urine } & \multicolumn{3}{|c|}{ Bicarbonate } & \multirow{2}{*}{$\begin{array}{l}\text { Plasma } \\
\text { volume }\end{array}$} \\
\hline & $\mathrm{pH}$ & $\mathrm{PCO}_{2}$ & $\mathrm{HCO}_{3}^{-}$ & V & $\mathrm{pH}$ & $\mathrm{TA}$ & $\mathrm{NH}_{4}^{+}$ & $\mathrm{C}_{\text {In }}$ & $\begin{array}{l}\text { Fil- } \\
\text { tered }\end{array}$ & $\begin{array}{c}\text { Ex- } \\
\text { creted }\end{array}$ & $\begin{array}{c}\text { Re- } \\
\text { ab- } \\
\text { sorbed }\end{array}$ & \\
\hline $\min$ & & $\begin{array}{l}\mathrm{mm} \\
\mathrm{Hg}\end{array}$ & mmoles/1 & $\begin{array}{c}\mathrm{ml} / \\
\mathrm{min} / \\
1.73 \mathrm{~m}^{2}\end{array}$ & & $\begin{array}{r}\mu \mathrm{Eq} \\
100 \mathrm{~m}\end{array}$ & $\begin{array}{l}\min / \\
\text { GFR }\end{array}$ & $\begin{array}{c}\mathrm{ml} / \\
\mathrm{min} / \\
1.73 \mathrm{~m}^{2}\end{array}$ & $\mathrm{mmol}$ & $\mathrm{es} / 100 \mathrm{~m}$ & $1 \mathrm{GFR}$ & $\mathrm{ml}$ \\
\hline
\end{tabular}

$$
\begin{array}{r}
-300 \\
\text { to }-240 \\
-85 \\
0
\end{array}
$$$$
\mathrm{NH}_{4} \mathrm{Cl}^{1}
$$$$
\text { start infusion }{ }^{2}
$$$$
\text { priming dose of inulin }{ }^{3}
$$

2 infusion as above with addition ${ }^{4}$

$48-68$

$\begin{array}{lllll}7.38 & 33.5 & 19.6 & 5.1 & 6.8 \\ 7.36 & 38.0 & 20.6 & 7.42 & 6.85\end{array}$

$\begin{array}{llll}67.1 & 1.96 & 0.064 & 1.896 \\ 68.6 & 2.06 & 0.068 & 1.992 \\ & & & \\ 75.9 & 2.12 & 0.107 & 2.013 \\ 46.8 & 2.17 & 0.527 & 1.643 \\ 58.1 & 2.35 & 0.492 & 1.858\end{array}$
infusion as above with addition ${ }^{5}$

$\begin{array}{rlllll}98-108 & 7.36 & 38.5 & 21.2 & 5.7 & 7.08 \\ 109-125 & 7.39 & 36.7 & 21.7 & 8.2 & 7.41 \\ 126-148 & 7.41 & 38.3 & 23.5 & 9.1 & 7.44\end{array}$

$11 \mathrm{~g}$ given by mouth in a $10 \%$ solution in water.

24 parts $0.85 \% \mathrm{NaCl}$ and 1 part $5 \%$ glucose. Solution administered at rate of $5.6 \mathrm{ml} / \mathrm{min} / \mathrm{m}^{2}$.

$30.7 \mathrm{~g}$.

$47 \mathrm{~g} / \mathrm{l}$ inulin added to infusion.

${ }^{5}$ Containing 135 mmoles/l $\mathrm{HCO}_{3}^{-}$. 
Table V. Study of Patient C. St. under conditions of high plasma volume

\begin{tabular}{|c|c|c|c|c|c|c|c|c|c|c|c|c|}
\hline \multirow[t]{2}{*}{ Time } & \multicolumn{3}{|c|}{ Serum } & \multicolumn{5}{|c|}{ Urine } & \multicolumn{3}{|c|}{ Bicarbonate } & \multirow[b]{2}{*}{$\begin{array}{l}\text { Plasma } \\
\text { volume }\end{array}$} \\
\hline & $\mathrm{pH}$ & $\begin{array}{l}\mathrm{PCO}_{2} \\
.\end{array}$ & $\mathrm{HCO}_{3}^{-}$ & $\mathrm{V}$ & $\mathrm{pH}$ & TA & $\mathrm{NH}_{4}^{+}$ & $\mathrm{C}_{\mathrm{In}_{\mathrm{n}}}$ & $\begin{array}{l}\text { Fil- } \\
\text { tered }\end{array}$ & $\begin{array}{c}\text { Ex- } \\
\text { creted }\end{array}$ & $\begin{array}{c}\begin{array}{c}\mathrm{Re}- \\
\text { ab- } \\
\text { sorbed }\end{array} \\
\end{array}$ & \\
\hline $\min$ & & $\begin{array}{c}\mathrm{mm} \\
\mathrm{Hg}\end{array}$ & mmoles/l & $\begin{array}{c}\mathrm{ml} / \\
\mathrm{min} / \\
1.73 \mathrm{~m}^{2}\end{array}$ & & $\begin{array}{r}\mu \mathrm{Eq} \\
100 \mathrm{~m}\end{array}$ & min/ & $\begin{array}{c}\mathrm{ml} / \\
\mathrm{min} / \\
1.73 \mathrm{~m}^{2}\end{array}$ & $\mathrm{mmo}$ & les/100 n & $1 \mathrm{GFR}$ & $\mathrm{ml}$ \\
\hline
\end{tabular}

\begin{tabular}{|c|c|c|c|c|c|c|c|c|c|c|c|c|}
\hline $\begin{array}{r}-300 \\
\text { to }-240 \\
0 \\
2 \\
3\end{array}$ & $\begin{array}{c}\mathrm{NH}_{4} \mathrm{Cl} \\
7.30 \\
\text { primin } \\
\text { start in }\end{array}$ & $\begin{array}{l}26.5 \\
\text { dose o } \\
\text { usion }{ }^{3}\end{array}$ & $\begin{array}{l}13.8 \\
\text { inulin }\end{array}$ & & & & & & & & & \\
\hline $54-82$ & 7.29 & 31.5 & 15.7 & 2.0 & 5.6 & 85.1 & 48.1 & 39.5 & 1.57 & 0 & 1.57 & \\
\hline $83-110$ & 7.30 & 36.0 & 15.9 & 1.92 & 5.6 & 78.6 & 55 & 33.2 & 1.59 & 0 & 1.59 & \\
\hline 172 & infusior & as abo & with & ddition & & & & & & & & \\
\hline $169-194$ & 7.29 & 33 & 15.6 & 2.7 & 6.1 & & & 37.1 & & & & \\
\hline $195-207$ & 7.32 & 34 & 16.7 & 2.69 & 6.3 & 61.1 & & 35.8 & & & & \\
\hline $208-219$ & 7.34 & 34.5 & 17.2 & 2.92 & 6.62 & 57.1 & & 34.2 & 1.72 & 0.025 & 1.695 & 458 \\
\hline $220-231$ & 7.34 & 34 & 18.2 & 4.09 & 6.62 & 51.2 & & 43.6 & 1.82 & 0.025 & 1.805 & \\
\hline $232-242$ & 7.35 & 36 & 18.9 & 5.73 & 6.79 & 45.0 & & 56.6 & 1.89 & 0.051 & 1.839 & \\
\hline $243-260$ & 7.37 & 36.5 & 19.7 & 5.2 & 6.93 & 44.5 & & 46.5 & 1.97 & 0.154 & 1.816 & \\
\hline $261-273$ & 7.39 & 34.5 & 20.1 & 6.45 & 7.07 & 22.4 & & 49.7 & 2.01 & 0.134 & 1.876 & 468 \\
\hline
\end{tabular}

In figure 2 is shown the correlation between levels of excreted bicarbonate and serum bicarbonate in the low volume studies (solid circles) and in the high volume studies (ringed circles). The respective titration curves are drawn by inspection. The renal bicarbonate threshold corresponding to the two studies before extracellular fluid volume expansion (solid circles) is 21 mmoles/l, whereas that determined during the two studies with expansion is between 17 and $18 \mathrm{mmoles} / \mathrm{l}$. Thus there is a decrease of $3.5 \mathrm{mmoles} / \mathrm{l}$ in the renal bicarbonate threshold at a time when plasma volume had expanded 10 and $19 \%$, respectively.

\section{Discussion}

In these two patients with Lowe's syndrome, the excretion rates of TA and ammonium, following acute $\mathrm{NH}_{4} \mathrm{CI}$ loading, proved to be normal. In one of the studies, however, the absolute rate of excretion for TA did not reach the normal limit, but this value, when corrected for the low GFR, was also within normal limits. It is important to make this correction since the excretion of TA depends of the availability of urinary buffer [17]. The decreased excretion of TA can therefore be attributed to the low GFR. Urinary $\mathrm{pH}$ decreased normally after $\mathrm{NH}_{4} \mathrm{Cl}$ loading. The defect in production of ammonium observed by ABBAssi et al. [1] following chronic acid loading was not found in the present studies. Although the methods used were clearly different, normal rates of excretion of ammonium during acute acidosis with deficient excretion of ammonium during chronic acidosis have not been described to our knowledge. We were able to demonstrate no defect in renal excretion of TA or ammonium or in the ability to establish a pH gradient, and there is no reason to assume a distal tubular defect in these two patients.

No attempt was made to calculate the hydrogen ion clearance index as proposed by EukinTon et al. [6]. The assumption of a fixed relation between blood $\mathrm{tCO}_{2}$ and rates of excretion of hydrogen ion has been shown of questionable physiologic validity [5]. The relation 
between the two parameters depends largely on the total $\mathrm{CO}_{2}$ content of the blood and seems to be curvilinear. This more appropriate relation has been used for comparison in these studies (fig. 1).

The renal bicarbonate threshold has been reported by SorIano et al. [20] to be 21.5 to $22.5 \mathrm{mmoles} / \mathrm{l}$ in infants, and by PrTrs et al. [11] and by Soriano et al. [21] to be between 24 and 28 mmoles/ 1 in adults. In children it is probably intermediary. In our studies, when endogenous extracellular fluid volume was unaltered by using low infusion rates of the test substances, both patients exhibited a bicarbonate threshold slightly below that of infants and probably distinctly below that of two-year-old children. In the patients in this study, the renal bicarbonate threshold was therefore diminished for age as well as for weight. Thus, the renal tubular acidosis was a consequence of a renal bicarbonate leak alone and fits the definition of proximal renal tubular acidosis [20, 21], which is, defective renal bicarbonate reabsorption with normal ability to excrete acid urine.

Both patients demonstrated a distinct renal insufficiency; as a result, one could anticipate some decrease in renal bicarbonate threshold, similar to that observed by Rieselbach et al. [16]. These authors link the depressed glucose reabsorption of uremic man to an effect of the so-called third factor. The decrease of renal bicarbonate threshold in the present observations might be explained by this same mechanism. The third factor has been studied extensively in animal experiments, mainly with respect to tubular sodium reabsorption. Characteristically, its action is independent of changes of GFR or mineralocorticoid activity. Most recently, the action of the third factor in modulating sodium reabsorption has been demonstrated in uremic man [19]. The fraction of filtered sodium reabsorbed in renal insufficiency is less than that in the normal condition. Furthermore, sodium reabsorption seems to be intimately linked with hydrogen ion excretion and with bicarbonate reabsorption [14]. If sodium reabsorption is depressed in renal insufficiency, therefore, bicarbonate reabsorption can be expected to decrease simultaneously. Our data in two patients with a moderate degree of renal insufficiency are compatible with this view. The chronically dehydrated children showed a moderate degree of acidosis when the extracellular fluid volume was unaltered.

The clinical observation of a slight, chronic dehydration of both patients seems eminently important, since the action of the third factor is counteracted effectively by reduction of effective vascular volume [3, 9, 10$]$. A relatively low plasma volume in these patients would counteract the effect of the third factor and would protect them from a more severe bicarbonate loss. Cionversely, rehydration or expansion of plasma volume should induce an additional loss of bicarbonate. We found a slight bicarbonate leak associated with chronic dehydration and, with expansion of extracellular fluid volume, a further decrease of the renal bicarbonate threshold. This explained the dependence of renal bicarbonate threshold on plasma volume and it was therefore concluded that in the well-hydrated state, the patients in this study would have demonstrated a lower renal bicarbonate threshold. Chronic dehydration probably preserves the kidneys from a more pronounced proximal tubular acidosis.

An effect of extracellular volume on renal handling of bicarbonate has been suspected clinically in a case of Fanconi syndrome with proximal tubular acidosis reported by RAMPINI et al. [13]. These authors observed that hydrochlorothiazide was able to partially correct the acidosis, but no physiologic data were given to prove the suspicion. Direct physiologic evidence of the dependence of renal bicarbonate reabsorption on extracellular volume has been given in animal experiments, however [7, 12]. It is concluded that our study provides evidence that the same mechanism exists in man.

\section{Summary}

In two patients with Lowe's syndrome and with renal tubular acidosis, the excretion rates of titratable acid and ammonium, as well as the ability to excrete an acid urine, have been shown to be normal. The decreased renal bicarbonate threshold present in both patients, however, established the diagnosis of proximal renal tubular acidosis.

Evidence has been presented that the renal bicarbonate threshold is directly dependent on the plasma volume. New aspects of the pathophysiology of renal tubular acidosis in Lowe's syndrome have been discussed.

\section{References and Notes}

1. Abbassi, V.; Lowe, C.U. and Galcagno, P.L. : Oculo-Cerebro-Renal Syndrome. Amer.J.Dis. Child. Vol. 115: 145-168 (1968).

2. Davidson, W.D. and Sackner, M.A.: Simplification of the anthron method for the determination of inulin in clearance studies. J. Lab. clin. Med. 62: 351-356 (1963).

3. Davis, J.O.; Holman, J.E.; Carpenter, C. C.J.; URQUHART, J. and Higgins, J.T., Jr.: An extra adrenal factor essential for chronic renal sodium retention in presence of increased sodium-retaining hormone. Circulat. Res. 14: 17-31 (1964).

4. Edelmann, C. M., Jr.; Soriano, J. R.; Borchis, H.; Gruskin, A. B. and Acosta, M. I.: Renal bicarbo- 
nate reabsorption and hydrogen ion excretion in normal infants. J.clin. Invest. 46: 1309-1317 (1967).

5. Edelmann, G. M., Jr.; Botchis, H.; Soriano, J.R. and Stark, H.: The renal response of children to acute ammonium chloride acidosis. Pediat. Res. $l$ : 452-460 (1967).

6. Elkinton, J.R.; Huth, E.J.; Webster, G.D., Jr. and MCGANCE, R.A.: The renal excretion of hydrogen ion in renal tubular acidosis. I. Quantitative assessment of the response to ammonium chloride as an acid load. Amer.J. Med. 29: 554-575 (1960).

7. Kunau, R.; Frick, A.; Rector, F.G., Jr. and SELdrn, D.W.: Effect of extracellular fluid (ECF) volume expansion, $\mathrm{K}^{+}$deficiency and $\mathrm{pCO}_{2}$ on bicarbonate reabsorption in the rat kidney. Clin. Res. 14: 380 (1966).

8. Lamy, M.; Frezal, J.; Rey, J. et Larsen, C.: Etude métabolique du syndrome de Lowe. Rev. franç. clin. Biol. 7: 271-283 (1962).

9. Levinsky, N.G. and Lalone, R.C.: Sodium excretion during acute saline loading in dogs with vena caval constriction. J.clin. Invest. 44: 565-573 (1965).

10. Oetliker, O.; Shrock, P.; Gruskin, A. B.; Wolfiscre, N.M. and Edelmann, C.M., Jr.: Role of renal arterial pressure in the antinatriuresis of portal vein constriction (in press).

11. Pitts, R.F.; Ayer, J. L. and Schiess, W.A.: The renal regulation of acid base balance in man. III. The reabsorption and excretion of bicarbonate. J.clin. Invest. 28: 35-44 (1949).

12. Purkerson, M.; Lubowitz, H. and Bricker, N.S.: The genesis of the bicarbonate leak in chronic renal disease. Clin. Res. 15: 367 (1967).

13. Rampini, S.; Fanconi, A.: Illig, R. and Prader, A.: Effect of hydrochlorothiazide on proximal renal tubular acidosis in a patient with idiopathic 'de Toni-Debré-Fanconi syndrom'. Helv. paediat. Acta 23: 13-21 (1968).

14. Rector, F.C., Jr.; Garter, N.W. and Seldin,
D.W.: The renal transport of hydrogen ion. Proc. III. Int. Congr. Nephrology, Washington 1966, vol. 1, 76-85 (1966).

15. Richterich, R.: Klinische Chemie, pp.223-226 (Karger, Basel/New York 1965).

16. Rreselbach, R. E.; Shankel, S.W.; Slatopolsky, E.; Lubowitz, H. and Bricker, N. S.: Glucose titration studies in patients with chronic progressive renal disease.

J. clin. Invest. 46: 157-163 (1967).

17. Schiess, W.A.; Ayer, J.L.; Lotspeich, W.D. and PItrs, R.F.: The renal regulation of acid-base balance in man. II. Factors affecting the excretion of titrable acid by the normal human subject. J. clin. Invest. 27: 57-64 (1948).

18. Seligson, D: and Seligson, H.: Microdiffusion method for the determination of nitrogen liberated as ammonia. J. Lab. clin. Med. 38: 324-330 (1951).

19. Slatopolsky, E.; Elkan, I.O.; Weerts, S. and BRICKER, N.S.: Studies on the characteristics of the control system governing sodium excretion in uremic man. J.clin. Invest. 47: 521-530 (1968).

20. Soriano, J.R.; Boichis, H. and Edelmann, G. M., Jr.: Bicarbonate reabsorption and hydrogen ion excretion in children with renal tubular acidosis. J.Pediat. 71: 802-813 (1967).

21. Soriano, J.R.; Borchis, H.; Stark, H. and EdelMANN, C. M., Jr.: Proximal renal tubular acidosis. A defect in bicarbonate reabsorption with normal urinary acidification. Pediat. Res. 1: 81-98 (1967).

22 . We gratefully acknowledge the most valuable technical assistance of Miss Susanne Aeberhard and Miss Sigrid Schultz. We thank Dr. A. Donath of the Department of Pediatrics, University of Berne, for the determination of plasma volume and Dr. R. Martin du Pan, P.D., Faculté de Médicine de Genève, for the preliminary work-up of patient C. St.

23. Requests for reprints should be addressed to: Oskar Oetliker, M.D., Department of Pediatrics, University of Berne, Inselspital, Berne (Switzerland). 